\title{
KUALITAS BRIKET ARANG DARI BATANG KELAPA SAWIT (Elaeis guineensis Jacq) BERDASARKAN UKURAN SERBUK
}

\author{
(The Quality of Charcoal Briquette from Oil Palm Frond (Elaeis guineensis Jacq) Based on \\ Particle Size of Charcoal)
}

\author{
Oki Herli Usmayadi, Nurhaida, Dina Setyawati \\ Fakultas Kehutanan Universitas Tanjungpura. Jln Imam Bonjol Pontianak 78124 \\ Email : oki.herli@gmail.com
}

\begin{abstract}
The research aimed to evaluate the influence of particle size of charcoal from oil palm fronds on the properties of charcoal briquette. The quality of charcoal briquette was evaluated according to Standar Nasional Indonesia (SNI) 01-6235-2000. The methods use Completely Random Design with factor the particle size. The particle size consist of three size, the first particle loss of 10 mesh and retained 20 mesh; the second particle loss of 20 mesh and retained 40 mesh and the third particle loss of 40 mesh and retained 60 mesh. The quality of charcoal consist of moisture content, ash content, fixed carbon, calor value and flying material. The result of research showed that the average value of moisture content was $8.49 \%-12.41 \%$, ash content was $7.34 \%-8.78 \%$, flying materials was $13.71 \%$ - $21.08 \%$, fixed carbon was $71.57 \%-77.50 \%$ and calor value was $5124 \mathrm{kkal} / \mathrm{kg}-5338 \mathrm{kkal} / \mathrm{kg}$. The research result concludes that the best charcoal briquet is on particle size which loss of 10 mesh and retained 20 mesh. This charcoal fulfilled the Indonesian National Standard (INS) 01-6235-2000.
\end{abstract}

Keywords: bioenergy, charcoal briquette, Elaeis guinensis, oil palm frond, particle size

\section{PENDAHULUAN}

Pemenuhan kebutuhan energi bahan bakar fosil masih menjadi masalah yang harus dihadapi masyarakat saat ini. Semakin bertambahnya kebutuhan energi membuat banyak pihak harus berpikir untuk tidak selalu bergantung pada sumber energi dari bahan fosil yang digunakan. Oleh karena itu, masyarakat membutuhkan solusi untuk mengatasi masalah yang ditimbulkan akibat krisisnya bahan bakar fosil. Salah satunya yaitu pemanfaatan limbah pelepah kelapa sawit yang berpotensi sebagai bahan bakar alternatif terbaharukan dengan harga yang lebih murah, ramah lingkungan, ketersediaan melimpah dan penggunaan yang mudah. Pelepah kelapa sawit (Elaeis guieneensis. Jacq) yang sudah tua dan tidak digunakan merupakan salah satu limbah yang ada di perkebunan kelapa sawit. Limbah pelepah kelapa sawit ini dapat dimanfaatkan sebagai briket arang.

Pembuatan briket arang dapat dilakukan dengan cara penambahan perekat tapioka, dimana bahan baku diarangkan terlebih dahulu kemudian ditumbuk, dicampur perekat dan dicetak (kempa dingin) dengan sistem hidrolik manual dan selanjutnya dikeringkan (Pari, 2002). Menurut Sulistyowati (2010) hasil penelitian diperoleh briket arang yang terbaik pada perlakuan 
tempurung kelapa $100 \%$ dan kulit batang sagu $0 \%$, dengan lolos ayakan 40 mesh tertahan 60 mesh. Kemudian pada perlakuan tempurung kelapa $50 \%$ dan kulit batang sagu $50 \%$ dengan ukuran serbuk lolos ayakan 40 mesh tertahan 60 mesh, yang memiliki nilai kalor masing-masing $6440 \mathrm{kkal} / \mathrm{kg}$ dan $6010 \mathrm{kkal} / \mathrm{kg}$. Melihat fenomena tersebut dilakukanlah penelitian mengenai pemanfaatan limbah pelepah kelapa sawit (E. guineensis. Jacq) untuk dibuat briket arang dengan perlakuan berbagai jenis ukuran serbuk dengan perekat tapioka sehingga menghasilkan kualitas yang optimal

Penelitian bertujuan untuk mengetahui pengaruh arang pelepah kelapa sawit terhadap kualitas briket arang dan mengetahui ukuran serbuk yang terbaik dalam pembuatan briket arang dari pelepah kelapa sawit. Manfaat penelitian diharapkan dapat memberikan informasi kepada masyarakat mengenai pemanfaatan pelepah kelapa sawit untuk dijadikan sebagai bahan baku pembuatan briket arang sebagai salah satu energi alternatif terbarukan

\section{METODE PENELITIAN}

Penelitian dilaksanakan di Laboratorium Wood Workshop dan, Laboratorium Pengolahan Kayu di Fakultas Kehutanan Universitas Tanjungpura, Laboratorium Agronomi dan Klimatologi di Fakultas Pertanian Universitas Tanjungpura, dan Laboratorium Kimia Hasil Hutan di Institut Pertanian Bogor. Penelitian dilakukan selama \pm 2 bulan mulai dari persiapan, pengerjaan dan pengujian sampai pengolahan data.

Proses pembuatan briket arang dimulai dengan pemotongan limbah pelepah kelapa sawit dengan ukuran \pm $5-10 \mathrm{~cm}$ agar mempermudah proses pengarangan, setelah itu dimasukkan ke dalam tanur selama 5-7 jam dengan suhu $450^{\circ} \mathrm{C}-500^{\circ} \mathrm{C}$. Arang potongan pelepah kelapa sawit selanjutnya dihaluskan dengan cara ditumbuk dalam lumpung dan diayak menggunakan mesin pengayak dengan ukuran saringan $10 \mathrm{mesh}$, saringan $20 \mathrm{mesh}$, saringan 40 mesh, dan saringan 60 mesh dengan tiga kali ulangan. Masingmasing serbuk arang yang lolos saringan dikumpulkan dalam plastik yang berbeda. Serbuk arang dimasukkan kantong plastik dan ditimbang sebanyak 25 gram, setelah itu dicampurkan dengan perekat tapioka yang diaduk secara merata. Campuran tersebut dicetak secara manual dengan memasukkan campuran serbuk arang dan perekat tapioka ke dalam alat pencetak dan dipres menggunakan alat pencetak briket sederhana selama 30 detik. Briket arang yang sudah dipres selanjutnya dikeringkan di dalam oven selama 24 jam dengan suhu $60^{\circ} \mathrm{C}-70^{\circ} \mathrm{C}$.

Kualitas briket arang diuji mengacu SNI 01-6235-2000 yaitu kadar air, kadar abu, kadar zat terbang, kadar karbon terikat dan nilai kalor. Analisis karakteristik pembakaran diuji dengan metode Water Boiling Test (WBT). Penelitian menggunakan Rancangan Acak Lengkap (RAL) model linier dengan satu faktor yaitu perbedaan ukuran serbuk dengan tiga kali ulangan. 
JURNAL TENGKAWANG (2018)

Vol. 8 (1) : 18 - 25

HASIL DAN PEMBAHASAN

Kadar Air

Kadar air rerata briket arang
Jacq) berkisar antara 8,49 \% - 12,41\%

(Gambar 1). pelepah kelapa sawit (E. gunieensis

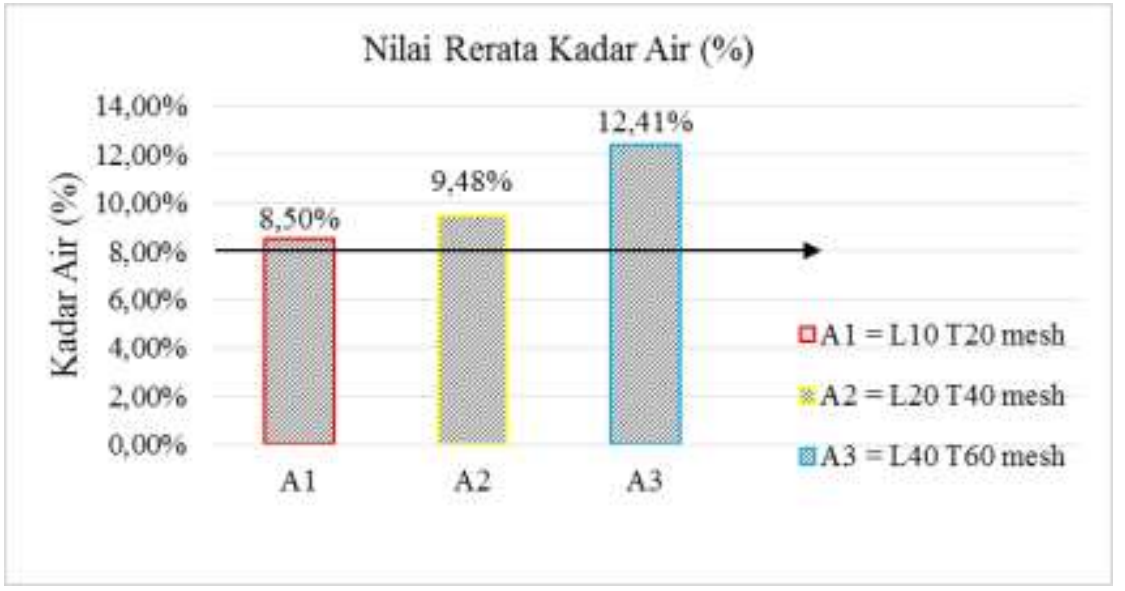

Gambar 1. Nilai Rerata Kadar Air Briket Arang Pelepah Kelapa Sawit (Average value of charcoal briquet water content from oil palm frond)

Faktor ukuran serbuk berpengaruh nyata terhadap nilai kadar air briket arang. Briket arang dari partikel lolos 10 mesh tertahan 20 mesh memiliki rata-rata kadar air lebih rendah daripada ukuran partikel lainnya. Nilai kadar air cenderung meningkat dengan semakin halusnya ukuran serbuk. Rendahnya kadar air pada briket arang dengan ukuran partikel lolos 10 mesh tertahan 20 mesh disebabkan karena ukuran serbuk arang yang lebih kasar daripada perlakuan yang lainnya sehingga air terserap lebih sedikit. Kadar air briket arang berpengaruh terhadap nilai kalor. Semakin kecil nilai kadar air, maka semakin tinggi nilai kalornya (Santosa dkk 2010).

Menurut Usman (2007) kadar air rendah disebabkan belum sempurnanya pengeringan dengan waktu pengeringan dalam oven, sehingga masih perlu diperpanjang waktu pengeringannya.
Selain itu ukuran partikel juga dapat mempengaruhi kadar air, partikel yang kasar lebih sedikit menyerap air dibanding dengan partikel yang lebih halus. Perlakuan yang mendekati Standar Nasional Indonesia (SNI) 016235-2000 dengan nilai kadar air maksimal $8 \%$ adalah pada perlakuan ukuran sebuk arang lolos 10 mesh tertahan 20 mesh yaitu dengan rerata $8,4973 \%$. Briket arang dengan ukuran partikel lainnya tidak memenuhi standar SNI.

Kadar Abu

Nilai rerata kadar abu berkisar antara 7,34 \% - 8,78 \%. Nilai kadar abu tertinggi pada briket arang dengan ukuran serbuk arang lolos 10 mesh dan tertahan 20 mesh. Nilai kadar abu terendah pada briket arang dengan ukuran partikel lolos 40 mesh tertahan 60 mesh. Kandungan kadar zat terbang yang tinggi di dalam briket arang akan 
menyebabkan asap yang lebih banyak pada saat briket arang dibakar. Hal ini disebabkan sebelum dijadikan briket arang mengalami proses pengarangan terlebih dahulu sehingga terjadi proses karbonisasi sehingga kandungan zat terbang yang terdapat pada serbuk banyak yang terbuang. Hal ini sesuai dengan pernyataan Triono (2006) yang menyatakan bahwa tinggi rendahnya kadar zat terbang pada briket arang diduga disebabkan oleh kesempurnaan proses karbonisasi dan juga dipengaruhi oleh waktu dan suhu pada proses pengarangan. Nilai kadar abu briket arang dari pelepah kelapa sawit disajikan pada Gambar 2.

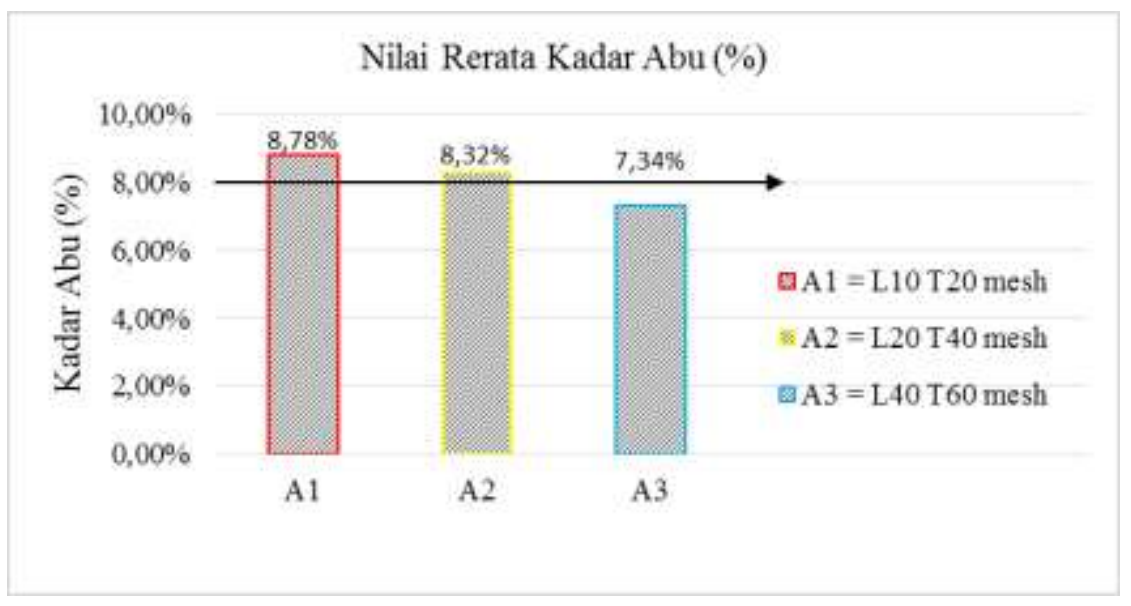

Gambar 2. Nilai Rerata Kadar Abu Briket Arang Pelepah Kelapa Sawit Grafik (Average value of ash content of charcoal briquette from oil palm frond)

Rendahnya kadar abu menunjukkan bahwa kualitas briket arang tersebut baik. Menurut Jamilatun (2011), abu yang terkandung dalam bahan bakar padat adalah mineral yang tidak dapat terbakar tertinggal setelah proses pembakaran dan reaksi-reaksi yang menyertainya selesai. Abu akan menurunkan mutu bahan bakar padat karena dapat menurunkan nilai kalor.

Perlakuan yang memenuhi standar SNI 01-6235-2000 adalah pada perlakuan (A1) dengan ukuran sebuk arang lolos 10 mesh tertahan 20 mesh dan perlakuan (A2) yaitu dengan rerata $8,1482 \%$ dan hanya pada perlakuan (A3) yang sesuai SNI 01-6235-2000. Briket arang yang memiliki nilai rerata kadar abu yang rendah disebabkan senyawa-senyawa organik yang terdapat pada perlakuan tersebut lebih rendah dan ukuran yang semakin halus (Sulistyowati, 2010).

Kadar Zat Terbang

Nilai rerata kadar zat terbang berkisar antara $13,71 \%-21,08 \%$ (Gambar 3). 
JURNAL TENGKAWANG (2018)

Vol. 8 (1) : 18 - 25

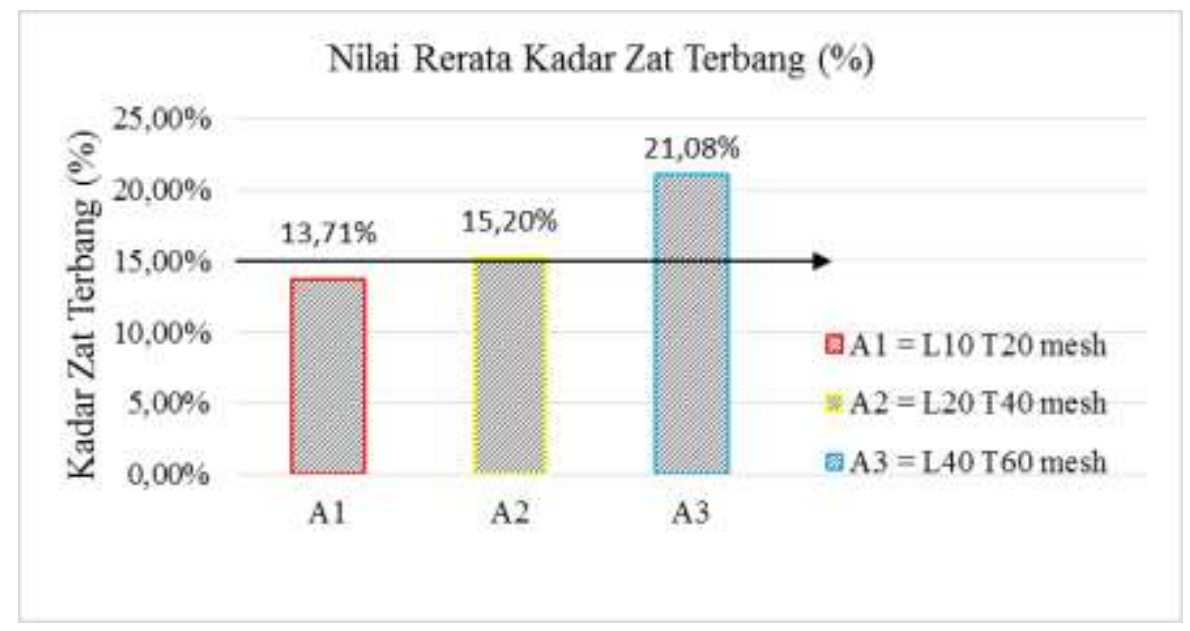

Gambar 3. Nilai Rerata Kadar Zat Terbang Briket Arang dari Pelepah Kelapa Sawit (Average value of fly content of charcoal briquet from oil palm frond)

Kadar zat terbang tertinggi terdapat pada perlakuan (A3) dengan ukuran serbuk arang lolos 40 mesh dan tertahan 60 mesh, sedangkan kadar zat terbang terendah terdapat pada perlakuan (A1)

Semakin besar suhu dan waktu pengarangan maka semakin banyak zat menguap yang terbuang, sehingga pada saat pengujian kadar zat menguap akan diperoleh lebih rendah.

\section{Kadar Karbon Terikat}

Nilai rerata kadar abu berkisar antara $71,57 \%-77,50 \%$ (Gambar 4).

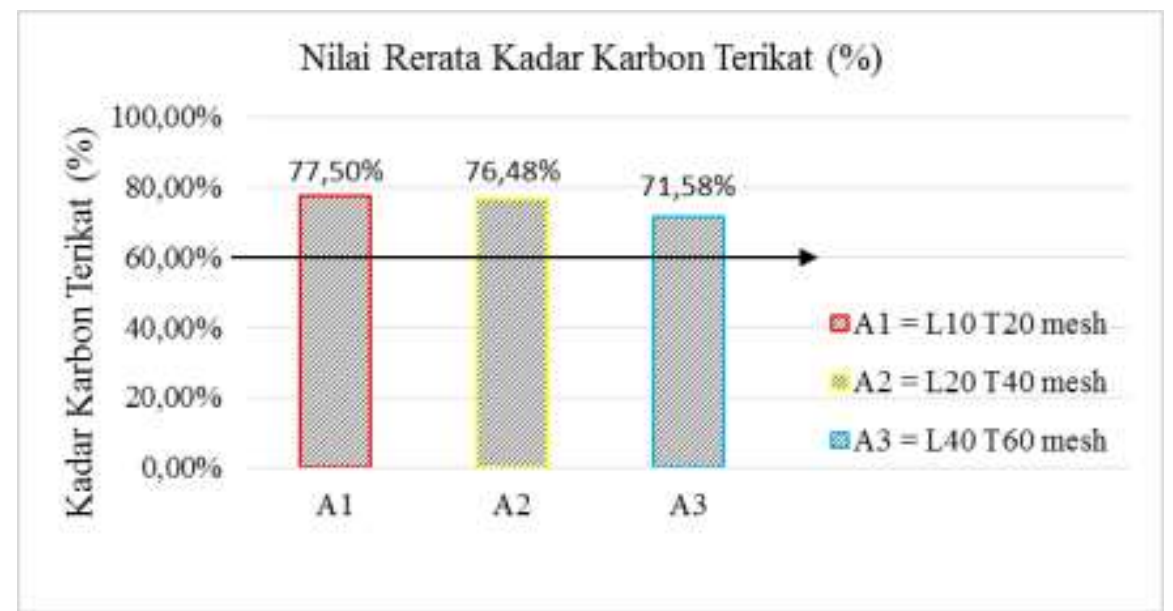

Gambar 4. Nilai Rerata Kadar Karbon Terikat Briket Arang dari Pelepah Kelapa Sawit (Average value of fixed carbon of charcoal briquet from oil palm frond)

Semua perlakuan sudah memenuhi SNI 01-6235-2000 dengan nilai karbon terikat sebesar $65 \%-80 \%$. Keberada an karbon terikat di dalam briket arang dipengaruhi oleh nilai kadar abu dan kadar zat terbang. Kadarnya akan bernilai tinggi apabila kadar abu dan kadar zat terbang briket arang tersebut rendah. Karbon terikat berpengaruh terhadap nilai kalor bakar arang briket. 
Nilai kalor arang briket akan tinggi apabila nilai karbon terikatnya tinggi.

Semakin tinggi kadar karbon terikat pada arang kayu maka menandakan arang tersebut adalah arang yang baik (Abidin, 1973 dalam Masturin, 2002). Semakin tinggi zat mudah terbang, maka semakin rendah nilai karbon terikat, begitu pula sebaliknya. Demikian juga bila kadar abu tinggi maka semakin rendah kadar karbon terikatnya, bila dibanding dengan standar briket arang (Nurhayati, 1976 dalam Usman 2007).

\section{Nilai Kalor}

Nilai kalor sangat menentukan kualitas briket arang. Semakin tinggi nilai kalor briket arang, semakin baik pula kualitas briketarang yang dihasilkan. Nilai kalor tertinggi yaitu pada perlakuan (A1) sebesar 5338 $\mathrm{kkal} / \mathrm{kg}$ dan nilai kalor yang terendah yaitu pada perlakuan (A2) sebesar 5124 kkal/kg. Berdasarkan grafik ukuran serbuk tidak berpengaruh nyata dengan nilai kalor (Gambar 5).

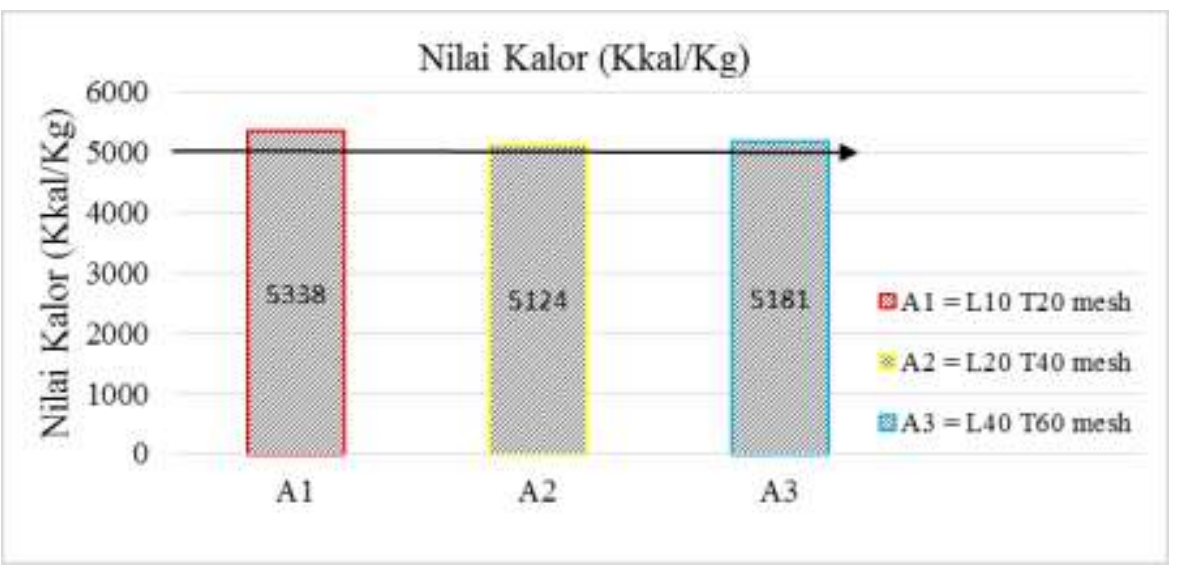

Gambar 5. Nilai Rerata Kalor Briket Arang dari Pelepah Kelapa Sawit (Average value of calor of charcoal briquet from oil palm frond)

Nilai kalor secara keseluruhan berkisar antara $5124 \mathrm{kkal} / \mathrm{kg}$ - 5181 $\mathrm{kkal} / \mathrm{kg}$ menunjukkan semua perlakuan sudah memenuhi SNI 01-6235-2000 dengan nilai kalor sebesar $5000 \mathrm{kkal} / \mathrm{kg}$. Menurut SNI 01-6235-2000 penetapan nilai kalor bertujuan untuk mengetahui sejauh mana nilai panas pembakaran pada briket arang tersebut. Menurut Nurhayati (1974) dalam Masturin (2002) nilai kalor dipengaruhi oleh kadar air dan kadar abu briket arang. Semakin tinggi kadar air dan kadar abu briket arang, maka akan menurunkan nilai kalor bakar briket arang yang dihasilkan.

\section{Analisis Karakteristik Pembakaran Briket Arang}

Waktu pendidihan 1 liter air tercepat selama 0,2306 jam (13 menit 50 detik) dengan menggunakan briket arang ukuran serbuk arang lolos saringan 40 mesh tertahan 60 mesh. Laju pembakaran briket arang yang tertinggi yaitu ukuran serbuk arang lolos saringan 40 mesh tertahan 60 mesh. Semakin cepat waktu pembakaran briket arang semakin besar 
juga laju pembakaran briket arang.

Kemudahan menyala sebagai salah satu

faktor yang mempengaruhi laju

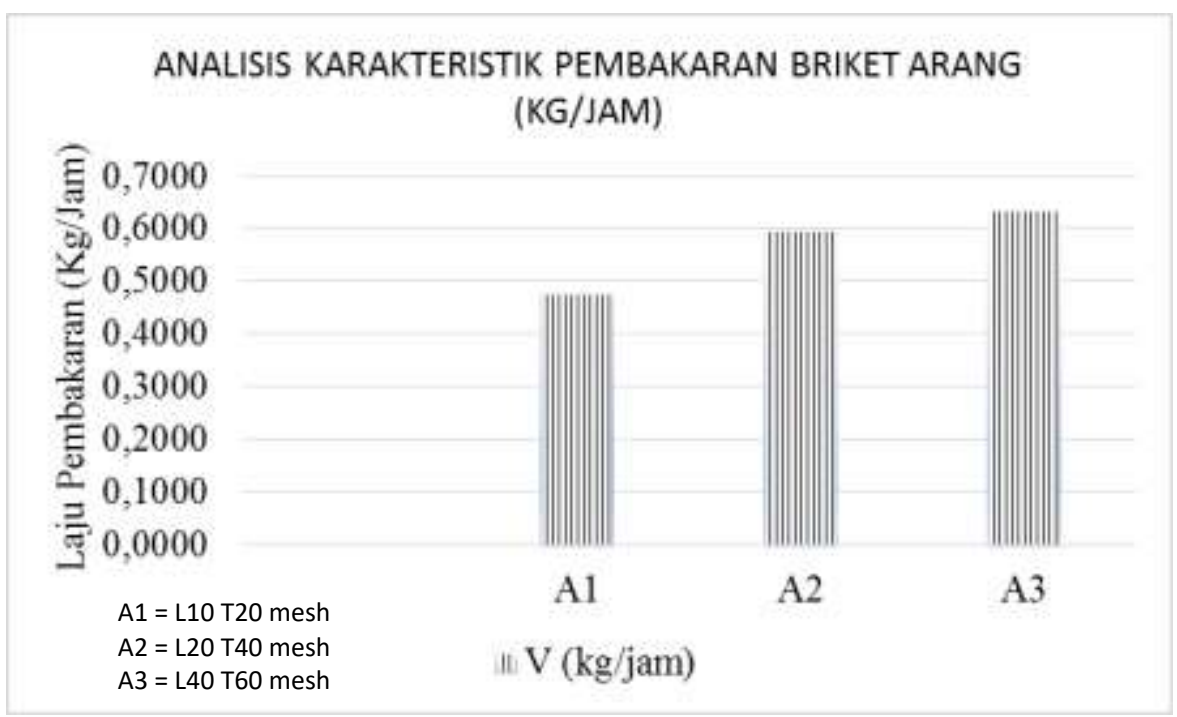

Gambar 6. Nilai Rerata Analisis Karaketristik Pembakaran Briket Arang dari Pelepah Kelapa Sawit (Average value of analysis characteristic of heat of charcoal briquet from oil palm frond)

\section{KESIMPULAN}

1. Ukuran serbuk berpengaruh terhadap nilai kadar abu, kadar zat terbang, kadar karbon terikat dan kadar air briket arang.

2. Briket arang yang memenuhi standar SNI 01-6235-2000 berdasarkan nilai kadar air dan kadar zat terbang hanya briket arang dari serbuk lolos 10 mesh tertahan 20 mesh, berdasarkan dari nilai kadar abu menunjukkan hanya perlakuan serbuk lolos 40 mesh dan tertahan 60 mesh yang memenuhi standar, berdasarkan nilai kadar karbon terikat dan nilai kalor menunjukkan semua perlakuan memenuhi standar.

3. Briket arang yang terbaik pada perlakuan ukuran serbuk arang lolos 10 mesh tertahan 20 mesh yang telah memenuhi SNI 01-62352000 kecuali pada nilai kadar abu.

\section{SARAN}

Perlu dilakukan penelitian dengan bahan baku limbah lain yang banyak menghasilkan selulosa dalam rangka memaksimalkan pemanfaaatan limbah hasil hutan bukan kayu untuk proses bioenergi.

\section{DAFTAR PUSTAKA}

Jamilatun S. 2011. Kualitas Sifat-sifat Penyalaan dari Pembakaran Briket Tempurung Kelapa, Briket Serbuk Gergaji Kayu Jati, Briket Sekam Padi dan Briket Batubara. Prosiding Seminar Nasional Teknik Kimia "Kejuangan". Malang

Masturin, A. 2002. Sifat Fisik dan Kimia Briket Arang dari Campuran Arang Limbah Gergajian Kayu. IPB.

Pari, G. 2002. Industri Pengolahan Kayu Teknologi Alternatif Pemanfaatan Limbah. IPB 
JURNAL TENGKAWANG (2018)

Vol. 8 (1) : 18 - 25

Rahman. 2011. Uji Keragaman Briket Arang Dari Biomassa Limbah Sekam Padi (Oryzasativa sp.) Sebagai Bahan Bakar Alternatif Terbarukan. IPB.

Santosa, Mislaini R., dan Swara Pratiwi Anugrah. 2010. Studi Variasi Komposisi Bahan Penyusun Briket dari Kotoran Sapi dan Limbah Pertanian. Padang: Universitas Andalas Kampus Limau Manis.

Standar Nasional Indonesia. 2000. SNI 01-6235-2000.

Sulistyowati A. 2010. Kualitas Briket Arang Berdasarkan Komposisi Bahan Baku dan Ukuran Serbuk. Untan. Pontianak.

Triono A. 2006. Karakteristik Briket Arang dari Campuran Serbuk Gergajian Kayu Afrika dan Sengon dengan Penambahan Tempurung Kelapa. Bogor: Fakultas Kehutanan, Institut Pertanian Bogor.

Usman N. 2007, Mutu Briket Arang Kulit Buah Kakao dengan Menggunakan kanji sebagai perkekat. Makassar. 